\title{
ПОСТАННЯ ПСИХОСОФІЙНОГО ДИСКУРСУ ТОЛЕРАНТНОСТІ
}

\author{
Фурман Анатолій \\ Західноукраїнський національний університет \\ м. Тернопіль, Україна \\ anatoliy_furman@yahoo.com \\ https://orcid.org/0000-0003-1550-6955 \\ Шаюк Ольга \\ Західноукраїнський національний університет \\ м. Тернопіль, Україна \\ olgashayuk@yahoo.com \\ https://orcid.org/0000-0002-9015-4219
}

Мета. У дослідженні вперше окреслено проблемне поле започаткування психософійного дискурсу толерантності, який науково проєктується розгорнути за вчинковим принципом В. А. Роменця, а також за методологічними підходами, нормативами і засобами вітакультурної методології наукової школи А. В. Фурмана.

Методи. Для реалізації мети наукового пошуку були використані методи: психологічного аналізу, проблемно-комунікативного синтезу, індуктивного переходу від конкретного до загального, логіко-змістової дедукції як сходження від загального до одиничного і конкретного, канонічного вчинення у його психософійному витлумаченні.

Результати. В контексті актуальності створення новітньої моделі/концепції толерантності системно розглянуто найбільш значущі точки іiі генези в найважливіших вимірах філософського та наукового осмислення, тенденції розуміння та інтерпретації цього ковітального феномену людського повсякдення, його формовияви суспільного уреальнення і суб'єктного життєзреалізування. Воднораз толерантність розкрито і як важливий концепт сучасного теоретичного мислення і професійного методологування, а також як інтегральну особистісну рису-якість. Однак найважливіша авторська ідея, що сформульована як надзавдання дослідження, полягає в тому, щоб обгрунтувати вчинок толерантності як вузловий осередок життєдіяльності і в першому предметному наближенні визначити його психософійні контури за допомогою системного набору методів: критичного аналізу, рефлексивного синтезу, логічної та емпіричної індукції, смислової дедукції 3 використанням

(C) Фурман А., Шаюк О., 2021. Ця стаття відкритого доступу на умовах CC BY-NC 4.0 
інтелектуальних засобів миследіяльності i професійного методологічного моделювання. Внаслідок отримано теоретичне обгрунтування моделі вчинку толерантності як взаємодоповнення чотирьох компонентів - ситуаційного, мотиваційного, діяльного і післядіяльного. Таке структурне узмістовлення канонічно організованого вчинення уможливило висвітлення векторів психософіі толерантності, аргументування продуктивності розробки психософійного напрямку вивчення толерантності як світоглядної універсалії, котра співвідносить ментальні і мовленнєві, емоційні та інтелектуальні, раціональні та ірраціональні, екзистенційні та моральні складові історичного досвіду людства, збагачує масову свідомість уявленнями про прийнятні форми, методи і засоби соціальних учинків, ситуаційної взаємодії та порозуміння, а відтак програмує життя всіх i кожного згідно iз законами гуманності, солідарності, співдружності.

Висновки. Проведене дослідження доводить, що евристичний напрям конструктивної розробки розлогої проблематики людської толерантності є не так іï детальним психологічним вивченням, як психософійним осмисленням, ціннісним наповненням i вчинково-канонічним зреалізуванням великих спільнот, малих груп i кожної особистості зокрема. Саме це дає змогу світоглядно програмувати життєвий шлях зрілої особи, яка стала на шлях розсудливого вчинення.

Ключові слова: толерантність, особистість, буття, учинення, психософія, вчинок, свідомість.

\section{Furman Anatoly, Shayuk Olga. Formation of psychosophical discourse of tolerance.}

Purpose. This is a study for the first time that outlines the problematic field of the beginning of the psychosophical discourse of tolerance which is scientifically projected to be developed according to the action principle of V.A. Roments, methodological approaches, standards and means of vitfcultural methodology of the scientific school A.V. Furman.

Methods. To realize the purpose of scientific research were used as methods: psychological analysis, problem-communicative synthesis, inductive transition from specific to general, logical-semantic deduction as the ascent from general to individual and specific, canonical commission in its psychosophical interpretation.

Results. In the context of the urgency of creating the latest model/concept of tolerance are systematically considered the most important points of its genesis in the most important dimensions of philosophical and scientific understanding, tendencies of understanding and interpretation of this covital phenomenon of human everyday life, and its manifestation of social and subjective realization. At the same time, tolerance is revealed as an important concept of modern theoretical thinking and professional methodology, as well as as an integral personal trait-quality. However, the most important author's idea was formulated as the overriding task of research, to justify the act of tolerance as a nodal center of life and in the first subject approximation to determine its psychosophical contours using a systematic set of 
methods: critical analysis, reflexive synthesis, logic and empiricism. semantic deduction with the use of intellectual means of thinking and professional methodological modeling. As a result, a theoretical substantiation of the model of tolerance as a complement of four components - situational, motivational, active and post-action. This structural interpretation of canonically organized action allowed to identify the vectors of the psychosophy of tolerance to assert the productivity of the psychosophical direction of the study of tolerance as a worldview universality that correlates mental and speech, emotional and intellectual, rational and irrational, moral and existential components of human consciousness. It enriches the mass consciousness with ideas about acceptable forms, methods and means of social action, situational interaction and understanding, and thus programs the life of everyone according to the laws of humanity, solidarity, and commonwealth.

Conclusions. As a result of the study it was concluded that the heuristic direction of constructive development of extensive issues of human tolerance is not so much in its detailed psychological study, as in psychosophical understanding, value and canonical implementation of large communities and small groups and individuals. This makes it possible to programmatically program the life path of a mature person who has embarked on the path of conscious action.

Key words: tolerance, personality, being, deed, psychosophy, deed, consciousness.

\section{Фурман Анатолий, Шаюк Ольга. Формирование психософийного дискурса толерантности.}

Цель. В исследовании впервые очерчено проблемное поле возникновения психософийного дискурса толерантности, который научно проектируется развернуть за принципом поступка В.А. Роменца, методологическими подходами, нормативами и средствами витакультурной методологии научной школы А.В. Фурмана.

Методы. Для реализации цели научного поиска были использованы методы: психологического анализа, проблемно-коммуникативного синтеза, индуктивного перехода от конкретного к общему, логико-содержательной дедукция как восхождение от общего к единичному и конкретному, каноническому совершению в его психософийном истолковании.

Результаты. В контексте актуальности создания новейшей модели/концепции толерантности системно рассмотрены наиболее значимые точки ее генезиса в важнейших измерениях философского и научного осмысления, тенденции понимания и интерпретации этого ковитального феномена человеческой повседневности, его общественные и субъктные формы. В то же время толерантность раскрыта и как важный концепт современного теоретического мышления и профессионального методологирования, а также как интегральная личностная черта-качество. Однако важнейшая авторская идея, сформулированная как сверхзадача исследования, состоит в том, чтобы обосновать поступок толерантности как узловой очаг жизнедеятельности и в первом предметном приближении 
определить его психософийные контуры с помощью системного набора методов: критического анализа, рефлексивного синтеза, логической и эмпирической дедукции с использованием интеллектуальных средств мыследеятельности и профессионального методологического моделирования. В результате получено теоретическое обоснование модели поступка толерантности как взаимодополнения четырех компонентов - ситуационного, мотивационного, деятельного и последеятельного. Такое структурное содержание канонически организованного совершения позволило показать векторы психософии толерантности, аргументировать продуктивность разработки психософийного направления изучения толерантности как мировоззренческой универсалии, которая соотносит ментальные и языковые, эмоциональные и интеллектуальные, рациональные и иррациональные, моральные и екзистенциальные составные человеческого опыта, обогащает массовое сознание представлениями о приемлемых формах, методах и средствах социальных поступков, ситуационного взаимодействия и взаимопонимания, и таким образом программирует жизнь всех и каждого по законам гуманности, солидарности, содружества.

Выводы. В итоге проведенного исследования говорится, что эвристическим направлением конструктивной разработки проблематики человеческой толерантности есть не столько ее детальное психологическое изучение, сколько психософийное осмысление, ценностное наполнение и ее поступочно-каноническая реализация как крупными сообществами, так и малыми группами и каждой личностью в частности. Именно это позволяет мировоззренчески программировать жизненный путь зрелого лица, ставшего на осознаный путь реализации своей жизни.

Ключевые слова: толерантность, личность, бытие, учение, психософия, поступок, сознание.

Вступ. Цінування різноманітності підкреслюе усвідомлення, визнання, розуміння та оцінювання людських відмінностей i обертається навколо створення інклюзивного середовища, в якому кожен відчуває себе шанованим. Йдеться про схвалення і прийняття чужої практики, думки та переконань, котре уможливлюється через культивування людським загалом толерантності.

Толерантність - бажана в суспільстві й одна 3 небагатьох суперечливих цінностей, що іiі значення зрідка ставиться під сумнів. Однак, зважаючи на конкретні ситуації, сучасні інтерпретації толерантності можуть бути проблематичними для використання їх як інструментальних. Толерантність, яку здебільшого розуміють як повагу та ввічливість до інших, можна сприймати i як більш відповідний та ефективний інструмент для послаблення ворожого 
напруження між окремими особами i групами; для того, щоб допомогти подолати минулий нерозв'язний конфлікт, не розчинити, а обмежити деструктивність суперечки, або, принаймні, призвести до позитивної динаміки. Однак і така промоція толерантності не має переконливих аргументів Навпаки - існує багато різних причин, які роблять іï універсальною, необхідною концепцією і ключовою цінністю людського загалу. Зокрема, йдеться про політичні i прагматичні, гносеологічні та епістемологічні, етичні та ін., котрі проаналізовані в рамках проєкту комплексного фундаментального дослідження толерантності як потенційної основи нової державної українотворчої ідеології (Фурман, 2013).

Оскільки проблема толерантності пов'язана не тільки з низкою принципових філософсько-світоглядних питань, а й iз соціальнофілософськими засадами пізнання буттєвих засновків миследіяльності та свідомості толерантної особистості, то очевидним кроком на шляху довершеного теоретичного аргументування ціннісної вагомості толерантності для сьогодення $\epsilon$ пошук та дослідження власне іiї психософійного дискурсу, що й зумовило мету цього дослідження.

Методи та процедура дослідження. У дослідженні застосовано методи психологічного аналізу, проблемно-комунікативного синтезу, індуктивного переходу від конкретного до загального, логікозмістової дедукції як сходження від загального до одиничного i конкретного, канонічного вчинення у його психософійному витлумаченні.

Обговорення результатів. Толерантність - цивілізаційна норма сьогодення. Такою її оголосила ЮНЕСКО в Декларації про принципи толерантності 16 листопада 1995 року: «Толерантність - це повага, прийняття і розуміння багатого різноманіття культур нашого світу, наших форм вираження і способів бути людиною» (ст. 1 п. 1). Відтоді цей день відзначається як Міжнародний день толерантності (Декларація принципів толерантності, 2015). Незважаючи на визнання на офіційному рівні й повсякденну актуальність, позиції толерантності не $є$ міцними і стабільними. Вони розхитані насамперед практичним недотриманням толерантності на міждержавному рівні, в сутичках між представниками різних релігійних конфесій, у відверто ворожому ставленні до того, що відрізняється. На жаль, перелік фактів інтолерантності можна 
продовжувати.

Та всупереч цьому, протягом останніх трьох століть їі визнано однією з фундаментальних цінностей. У сучасній суспільній риториці вона, як і раніше, посідає сильну позицію, хоча презентує доволі складну шкалу пріоритетів (Beaugrande, 1997; Garnsey, 2016; Milo, 2019). Проте тверде переконання в цінності толерантності дотепер не обгрунтоване відповідними теоретичними доказами, хоча задля прояснення розуміння i засад толерантності виконано багато досліджень як у світі, так і в Україні. Їх результати суттєві, але далеко не беззаперечні чи остаточні й здебільшого визначають тільки рівень готовності чи неготовності терпіти іншого і недостатньо виявляють глибинну сутність феномену толерантності. Водночас це спричинило чимало складнощів і протиріч, особливо коли йдеться про межі толерантності, тобто про те, наскільки i в яких ситуаціях толерантність має бути присутня та чи є в неї ліміти (Галицький, 2018; Мельник, 2012; Brown, 2009; Heyd, 1998). Крім того, неодностайність проглядається i в обгрунтуванні засновків, передумов, чинників та механізмів дії-перебігу цього ковітального явища. Адже толерантність як ставлення i поведінка $є$ складним явищем, оскільки містить контрастні компоненти прийняття i відторгнення, причини яких, як не парадоксально, знаходяться на різних рівнях - індивідуального і специфічного етичного комплексу особистості і загальнолюдської моралі (Шаюк, Фурман, 2019; Dalcourt, 2017; Forst, 2018; Guciykunst, Ting-Toomey, Chua, 2018).

Очевидним $\epsilon$ той факт, що розвинена суспільна свідомість оформила уявлення про толерантність як моральну рису-якість, тобто як людську чесноту, котра характеризує прийняття однією особою або групою інтересів, переконань, вірувань, звичок інших людей чи спільнот і виражається в гуманному прагненні досягти взаємного порозуміння та узгодження різних мотивів, установок, орієнтацій, не вдаючися до насильства, пригнічення людської гідності й натомість використовуючи гуманітарні можливості - діалог, роз'яснення, співпрацю, взаємодопомогу. В абстрагуванні така «знята» форма соціальних відносин людей пізнається як процедура взаємодії частин зі своїм цілим. I перше, що тут доводиться виділяти, - нетотожність, 3 одного боку, реально існуючої людини самій собі як цілісності, а 3 іншого - людського світу до свого природного й суб'єктивного середовища існування. 
Другим $\epsilon$ те, що особливо важко стверджувати принципи толерантності в соціальній свідомості в контексті доктринального домінування такого джерела розвитку як насильство, агресія, оскільки основну логіку мислення в епоху постмодерну задали три великі конфліктологи: Чарльз Дарвін, який виклав концепцію розвитку тільки через виживання і боротьбу видів, Карл Маркс, який висунув ідею про розвиток тільки через антагонізм класів, через їхню боротьбу і конфлікт і Зигмунд Фройд, який у своїх працях показав, що тільки конфлікт між свідомістю і несвідомим рухає розвитком особистості (Смазнова, 2019; Witenberg, 2019).

Третє. Постійними предикатами суперечності стосовно людини i людського світу $є$, як було зазначено, дійсні умови іiі буття і форми повсякденного спілкування. Самі ці предикати непостійні, нестатичні, вони змінюються, сприяють або перешкоджають появі інших, перестають існувати або недовго зберігаються. Це цілковита закономірна властивість розвитку людських стосунків. Це пояснює те, що протягом усіх історичних змін суспільства в різні епохи в людських взаєминах домінували зовсім різні ідеї, ідеологеми, світогляди (Капто, 2011; Свендсен, 2016; Beaugrande, 1997; Ellis, 2004).

Очевидно, що проблемогенні процеси сьогодення сучасного світу впливають на мінливість і адаптивність багатьох світоглядних систем та настановлень. Промовисті факти напружених суспільних відносин указують на потребу діалогу, обміну думками з метою особистісного взаємозбагачення громадян, на нагальність більш глибокого розуміння суті вчинкових явищ, їх причин і наслідків. А це означає, що своєчасним $\epsilon$ коригування i наукових уявлень про сутність толерантності, про дійсні суспільні зв'язки та узгодження з ідеями і принципами, які продукують національно-культурні, релігійні, соціальні, політичні, економічні реаліі.

Першою спробою такого багатопредметного та міжнаукового розв'язання цієї проблеми став проєкт комплексного фундаментального дослідження толерантності як потенційної основи нової державної українотворчої ідеології, запропонований у 2013 році А. В. Фурманом (Фурман, 2013). Автор здійснив філософськометодологічне обгрунтування генези толерантності як фактора сталого суспільного розвитку і чинника соціокультурної інтеграції українства в онтолого-феноменологічному, гносеолого- 
ноуменологічному, психосоціальному та психософійному засадничих напрямах його рефлексивного миследіяльнісного опрацювання. У зазначеному форматі також окремо аргументовано і презентовано продуктивність розробки онтолого-феноменологічного напряму вивчення толерантності (Фурман, Шаюк, 2015). Зокрема, досліджено толерантність як спосіб людського буття, а, отже, як вітакультурну форму його оприявнення у життєдіяльності людини.

Водночас в аналітичних рамках окресленого теоретикометодологічного рефлексування толерантності як онтофеноменальної форми буття ми раніше обгрунтували ії як засадничу цінність сучасної культури, як усвідомлену, осмислену і відповідальну життєву позицію, реалізація якої в кожній окремій ситуації має певний смисл і вимагає від толерантної особистості благодатного пошуку смислу і прийняття будь-якого іншого людського світу як рівноправного (Свендсен, 2016; Фурман, 2013; Фурман, Шаюк, 2015).

Дослідження толерантності у форматі гносеологоноуменологічного напряму дало змогу проаналізувати іiі як важливе поняття сучасного філософського i теоретичного осмислення та професійного методологування i презентувати в руслі гносеологічних, епістемологічних, герменевтичних, етикорелятивістських та синергетичних інтерпретацій (Шаюк, Фурман, 2018)). Таке логіко-змістове взаємодоповнення суттєво поглиблює розуміння толерантності і фундує эï як концепт, що базується на інтелектуальних ресурсах онтологічних поглядів на реальну дійсність i позиціонує іiі як певну гносеоноуменальну дійсність, що уможливлює усвідомлення і прийняття складності й багатомірності як самої життєвої реальності, так і варіативності іiі сприйняття, розуміння та оцінки різними людьми, а також відносності, неповноти і суб'єктивності особистих уявлень, персоніфікованих картин світу.

Дослідження толерантності в аспекті психосоціального теоретизування окреслює iï аналіз інтерпретаціями соціогенетичного, конфліктологічного, ксенологічного, інформаційно-комунікативного то особистісного підходів. Таке логічне і змістове поєднання сутнісно поглиблює розуміння толерантності й уможливлює іiі репрезентацію як психосоціальної цінності, що характеризується терпимим ставленням до іншого, другого чи альтернативного i $\epsilon$ важливою соціокультурною нормою, яка примножує і покращує результати співробітництва і загальнолюдського спілкування, а тому постає в 
суспільному житті як рамкова умова ефективності соціальних зв'язків, усталених i нових форм комунікативної взаємодій (Вітакультурна методологія, 2019; Сагановська, 2017; Смазнова, 2019). В особистісному вимірі вона закономірно самоорганізується як інтегральна риса індивідуального світу особистості, котра визначає іiі активну позицію у взаємостосунках 3 людьми незалежно від їхньої культурної, соціальної та національної приналежності, передбачає порозуміння в будь-яких, зокрема й у конфліктних умовах міжособистісної взаємодії (Шаюк, Фурман, 2019; Beaugrande, 1997; Witenberg, 2019).

Органічною причиною i наступним очевидним кроком подальшого поглибленого дослідження толерантності в усіх складних взаємозв'язках і суперечностях іiі розвитку, а, щонайважливіше, вчинкового утвердження є те, що толерантність постає сьогодні не тільки теоретичним концептом, а й об'єктивно існуючим явищем, котре потребує як теоретичної рефлексії, так і певного практичного втілення. Як було зазначено, толерантність пов'язана 3 низкою принципових філософсько-світоглядних питань, які торкаються розуміння людини, іiі ідентичності, можливостей і меж пізнання, діалогу культур і цивілізацій, прояснення епістемологічної ситуації щодо понятійного горизонту толерантної свідомості та умов іiі збагачення в сучасному світі, виявлення іiі морально-етичної матриці, духовних джерел i вершинних психоформ (Вітакультурна методологія, 2019; Психологія вчинку, 2012; Shayuk, 2017; Milo, 2019; Žižek, 2008). Тож пошук власне психософійного дискурсу толерантності як учинення, соціально-філософських засад пізнання буттєвих засновків толерантної миследіяльності довершить теоретичну модель толерантності й уможливить пізнання ії глибинної сутності.

Обгрунтування вчинку толерантності як вузлового осереддя буття через узмістовлення його ситуаційного, мотиваційного, діяльного і післядіяльного компонентів (див рис. 1): уможливить експериментальне дослідження iї глибинних механізмів та адекватної інтерпретації отриманих результатів. Таку модель слушно взяти за основу для розбудови системи рекомендацій щодо створення нових соціальних технологій закорінення толерантності у свідомість людей, виховання їі в кожного члена суспільства як права вільного вибору, як учинення не 3 примусу, а згідно 3 бажаннями і совістю, як 
унікальної психодуховної практики для творення себе, світу та їхнього солідарного співіснування.

1 - сидуашійний комшоненх вчинку.
тодерантності полягає в тому, що
через своєрідне поєднання культурно-
історичних, соціальних,
індивідуальних умов та психологічних
станів, властивостей, індивідуальної
природи особистості інтелектуальними
ресурсами створюєтья сукупність
значущостей толерантного співжиття
громадян як світоглядного орієнтиру,
котрий спрнчнюю певну форму
суб'єктності окремої особистості -
вчинкової активності, яка має спрямованість на діяння, центроване навколо унікальності людського бу, та пошуку пспхосоціальної опори ньому
4 - післядійовий ккомпонент виинку тодерантності: вторинне, постдійове осмислення змісту здійсненгх учшнковпх дій, усвідомлення результатів вчпнкового діяння та оцінювання, осмислення їх; реалізується через самоаналіз, критичне ставлення до власних дій; розвиває здатність усвідомлювати, оцінювати і вносити корективи у стратегію своєї поведінки, перебудовувати чи долати неадекватні установкі, ставлення, конструкті.

\section{Рис. 1. Структурне обгрунтування психософійних контурів учинку}

\section{толерантності}

Висновки i перспективи. Людина не може мислити себе незалежною від людського загалу, адже саме з ним вона перебуває у перманентному сутнісному зв'язку. Специфічні людські властивості соціальність, розумність, моральність - витікають із природи світу і $є$ свідченням іiі дотичності до фундаментальних тенденцій ковітального буття.

Водночас усвідомлення своєї причетності до всезагалу має спонукати людство до роздумів над можливістю благодатного співіснування, до розуміння, усвідомлення і пошанування інакшості в 
ньому. Така стратегія співжиття вимагає глибоких змін у свідомості суспільства та особистості зокрема, звільнення іiі від претензії на зверхність не тільки в політичній та етичній риториці, але й в основоположних уявленнях, в онтологічних i гносеологічних підвалинах, що означає формування толерантності як психософійної організованості, яка світоглядно програмуватиме життя кожного.

Психософія - це шлях до мудрості, шлях до того, як бути натхненним, спрямованим до світу в ролі активного, дійового партнера (В. А. Роменець). Постання психософійного дискурсу пов'язано із філософсько-психологічним обгрунтуванням учинку толерантності, щонайперше 3 узмістовленням його ситуаційного, мотиваційного, діяльного та післядіяльного компонентів.

Перспективи подальшого дослідження порушеної проблеми пов'язані 3 рефлексивно-методологічним опрацюванням двох теоретичних концентрів:

а) виявлення внутрішніх умов повноцінного толерантного вчинення на рівні особистості як натхненного дійового партнера соціальних стосунків;

б) упрозорення системи уявлень про закономірності становлення та виявлення у толерантному вчинковому діянні особистості, групи, спільноти сутності людського буття в його ситуаційній, екзистенційній та канонічній довершеності.

\section{Література}

1. Вітакультурна методологія. До 25-річчя наукової школи професора A. B. Фурмана: колективна монографія (2019). Тернопіль: ТНЕУ.

2. Галицький, I. (2018). Толерантність у правовому жстті сучасної України: монографія. Одеса: Feniks.

3. Декларація принципів толерантності (2015). Психологія і суспільство, 3, 59-61.

4. Капто, А. С (2011). Толерантність в контексті концепції «Культура світу». Безпека Евразії, 1, 175-181.

5. Психологія вчинку: шляхами творчості В.А. Ромения: зб. ст./ упоряд. П. А. Мясоїд; відп. ред. А. В. Фурман (2012). Київ: Либідь.

6. Сагановська, Т. П. (2017). Толерантність як важлива складова частина принципу ненасилля. Актуальні проблеми філософії та соиіології. Одеса, 19, 95-98.

7. Свендсен, Л. (2016). Філософія свободи. Львів: Видавництво Анетти Антоненко, Київ: Ніка-Центр. 
8. Смазнова І. С. (2019). Агресія і толерантність: філософсько-правовий дискурс: монографія. Одеса: Фенікс.

9. Мельник В. (Ред.). (2012). Толерантність як соиіально-культурний феномен: світоглядно-методологічний аспект: колективна монографія. Львів: ЛНУ імені Івана Франка.

10. Фурман, А. В. (2013). Генеза толерантності та перспективи українотворення (комплексний проект). Психологія і суспільство, 1, 6-20.

11. Фурман, А. В., Шаюк, О. Я. (2015). Толерантність як предмет онтофеноменологічного дискурсу. Психологія і суспільство, 3, 31-61.

12. Shayuk, O. (2017). Vitacultural Horizons of Tolerance Conceptual Cognition. Психологія $i$ суспільство, 1, 73-78. DOI: https://doi.org/10.35774/pis2017.01.073

13. Шаюк, О. Я., Фурман, А. В. (2018) Методологічні підходи до сутнісного пізнання толерантності у форматі гносеолого-ноуменологічного напряму філософування. Вітакультурний млин, 20, 28-35.

14. Шаюк, О., Фурман, А. (2019). Методологічні підходи до сутнісного пізнання толерантності у рамках психосоціального теоретизування. Психологія і суспільство, 2, 5-27. DOI: https://doi.org/10.35774/pis2019.02.005

15. Beaugrande, R. (1997) Text, Discourse, and Process,Toward a Multidisciplinary Science of Texts (Advances in Discourse Processes). Publisher: Ablex Pub.

16. Brown, W. (2009). Regulating Aversion: Tolerance in the Age of Identity and Empire. Princeton University Press.

17. Dalcourt, G. J. (2017). Tolerance. New Catholic University of America Press

18. Ellis, A. (2004). The Road to Tolerance: The Philosophy of Rational Emotive Behavior Therapy. Prometheus Books.

19. Forst, R. (2018). Toleranz im Konflikt: Geschichte, Gehalt und Gegenwart eines umstrittenen Begriffs. Suhrkamp.

20. Garnsey, P. (2016). Religious toleration in classical antiquity. Persecution and toleration. Studies in Church History, 1-12.

21. Guciykunst, W. B., Ting-Toomey S., Chua E. (2018). Culture and interpersonal communication. Nevrbury Park.

22. Heyd, D. (1998). Toleration: An Elusive Virtue Kindle Edition. Princeton University Press.

23. Milo, D. S. (2019). Good enough: the tolerance for mediocrity in nature and society. Harward University Press.

24. Žižek, Sl. (2008). Tolerance as an Ideological Category.Critical Inquiry. The University of Chicago Press. 34(4), 660-682 https://doi.org/10.1086/592539

25. Witenberg, R. T. (2019). The Psychology of Tolerance: Conception and Development: https://doi.org/10.1007/978-981-13-3789-5

\section{Referenses}

1. Furman, A.V. \& Furman, O.I. \& Shandruk S.K. \& Co (Eds.). (2019) 
Vitakulturna metodolohiia: antolohiia. Do 25-richchia naukovoi shkoly profesora A. V.Furmana [Vitacultural methodology: an anthology. To the $25^{\text {th }}$ anniversary of professor A.V. Forman's Scientific School]. Ternopil: TNEU. [in Ukrainian].

2. Ghalycjkyj, I. (2018). Tolerantnistj u pravovomu zhytti suchasnoji Ukrajiny: monoghrafija [Tolerance in the legal life of modern Ukraine: a monograph]. Odesa: Feniks. [in Ukrainian].

3. Deklaracija pryncypiv tolerantnosti [Declaration of principles on tolerance] (2015). Psykhologhija i suspiljstvo, 3, 59-61. [in Ukrainian].

4. Kapto, A. S (2011). Tolerantnistj v konteksti koncepciji «Kuljtura svitu» [Tolerance in the context of the concept "Culture of the world»]. Bezpeka Evraziji, 1, 175-181. [in Ukrainian].

5. Miasoid, P.A. \& Furman A.V. (Eds). (2012) Psykholohiia vchynku: shliakhamy tvorchosti V.A. Romentsia [Psychology act: the way of creativity, of Romenets V.A]. Kyiv: Lybid. [in Ukrainian].

6. Saghanovsjka, T. P. (2017). Tolerantnistj jak vazhlyva skladova chastyna pryncypu nenasyllja [Tolerance as an important part of the principle of nonviolence]. Aktualjni problemy filosofiji ta sociologhiji. Odesa, 19, 95-98. [in Ukrainian].

7. Svendsen, L. (2016). Filosofija svobody [Philosophy of freedom]. Ljviv: Vydavnyctvo Anetty Antonenko, Kyjiv: Nika-Centr. [in Ukrainian].

8. Smaznova I. S. (2019). Ahresiia i tolerantnist: filosofsko-pravovyi dyskurs: monohrafiia [Aggression and tolerance: philosophical and legal discourse: a monograph] Odesa: Feniks. [in Ukrainian].

9. Batsevych, F.S. \& Hrabovska, S.L. \& Darmoriz, O.V. \& Co.(Eds.) (2012). Tolerantnistj jak socialjno-kuljturnyj fenomen: svitoghljadnometodologhichnyj aspekt: kolektyvna monoghrafija [Tolerance as a socio-cultural phenomenon: worldview and methodological aspect: a collective monograph]. Ljviv: LNU imeni Ivana Franka. [in Ukrainian].

10. Furman, A. V. (2013). Gheneza tolerantnosti ta perspektyvy ukrajinotvorennja (kompleksnyj proekt) [Genesis of tolerance and prospects of Ukrainian formation (complex project]. Psykhologhija $i$ suspiljstvo, 1, 6-20. [in Ukrainian].

11. Furman, A. V., Shajuk, O. Ja. (2015). Tolerantnistj jak predmet ontofenomenologhichnogho dyskursu [Tolerance as a subject of ontophenomenological discourse]. Psykhologhija $i$ suspiljstvo, 3, 31-61. [in Ukrainian].

12. Shayuk, O. (2017). Vitacultural Horizons of Tolerance Conceptual Cognition. Psykhologhija $i$ suspiljstvo, 1, 73-78. DOI: https://doi.org/10.35774/pis2017.01.073 [in English].

13. Shajuk, O. Ja., Furman, A. V. (2018). Metodologhichni pidkhody do sutnisnogho piznannja tolerantnosti u formati ghnoseologho-noumenologhichnogho naprjamu filosofuvannja [Methodological approaches to the essential knowledge of tolerance in the format of epistemological and noumenological direction of philosophizing]. Vitakuljturnyj mlyn, 20, 28-35. [in Ukrainian]. 
14. Shajuk, O., Furman, A. (2019). Metodologhichni pidkhody do sutnisnogho piznannja tolerantnosti u ramkakh psykhosocialjnogho teoretyzuvannja. Psykhologhija i suspiljstvo, 2, 5-27. DOI: https://doi.org/10.35774/pis2019.02.005 [in Ukrainian].

15. Beaugrande, R. (1997) Text, Discourse, and Process,Toward a Multidisciplinary Science of Texts (Advances in Discourse Processes). Publisher: Ablex Pub.

16. Brown, Wendy (2009). Regulating Aversion: Tolerance in the Age of Identity and Empire. Princeton University Press.

17. Dalcourt, G. J. (2017). Tolerance. New Catholic University of America Press.

18. Ellis, A. (2004). The Road to Tolerance: The Philosophy of Rational Emotive Behavior Therapy. Prometheus Books.

19. Forst, R. (2018). Toleranz im Konflikt: Geschichte, Gehalt und Gegenwart eines umstrittenen Begriffs. Suhrkamp.

20. Garnsey, P. (2016). Religious toleration in classical antiquity. Persecution and toleration. Studies in Church History, 1-12.

21. Guciykunst, W. B., Ting-Toomey S., Chua E. (2018). Culture and interpersonal communication. Nevrbury Park.

22. Heyd, D. (1998). Toleration: An Elusive Virtue Kindle Edition. Princeton University Press.

23. Milo, D. S. (2019). Good enough: the tolerance for mediocrity in nature and society. Harward University Press.

24. Žižek, Sl. (2008). Tolerance as an Ideological Category.Critical Inquiry. The University of Chicago Press. 34(4), 660-682 https://doi.org/10.1086/592539

25. Witenberg, R. T. (2019). The Psychology of Tolerance: Conception and Development. https://doi.org/10.1007/978-981-13-3789-5

Received: 30.10.2021

Accepted: 15.11.2021 